\title{
Peer Review of "A Machine Learning Explanation of the Pathogen-Immune Relationship of SARS-CoV-2 (COVID-19), and a Model to Predict Immunity and Therapeutic Opportunity: A Comparative Effectiveness Research Study"
}

Eric Abbott, BASc EE, PEng, PE, MBA, MSEE

Medical Health Informatics Graduate Program, Northwestern University, Chicago, IL, United States

Corresponding Author:

Eric Abbott, BASc EE, PEng, PE, MBA, MSEE

Medical Health Informatics Graduate Program

Northwestern University

339 East Chicago Avenue

Chicago, IL

United States

Phone: 13125036950

Email: abbottericb@gmail.com

\section{Related Articles:}

Preprint https://preprints.jmir.org/preprint/23582

Author Responses to Peer-Review Reports https://med.jmirx.org/2020/1/e24739/

Published Article https://med.jmirx.org/2020/1/e23582/

(JMIRx Med 2020;1(1):e24765) doi: 10.2196/24765

\section{KEYWORDS}

infectious disease; SARS-CoV-2; COVID-19; public health; immunity: vaccinations; therapeutics; stem-cell growth factor-beta

This is a peer review submitted for the paper "A Machine Learning Explanation of the Pathogen-Immune Relationship of SARS-CoV-2 (COVID-19), and a Model to Predict Immunity and Therapeutic Opportunity: A Comparative Effectiveness Research Study."

\section{General Comments}

This paper is excellent and very timely given its importance as it relates to supporting forthcoming mass vaccinations to address COVID-19 and potential prioritization of such vaccinations based on the study findings.

\section{Specific Comments}
1. None
2. None
3. None

Major Comments

\section{Minor Comments}

4. Consider consistency of using COVID-19 vs SARS-CoV-2 (abstract vs text body).

\section{Conflicts of Interest}

None declared. 
Edited by G Eysenbach; this is a non-peer-reviewed article. Submitted 04.10.20; accepted 04.10.20; published 19.10.20.

Please cite as:

Abbott E

Peer Review of "A Machine Learning Explanation of the Pathogen-Immune Relationship of SARS-CoV-2 (COVID-19), and a Model to Predict Immunity and Therapeutic Opportunity: A Comparative Effectiveness Research Study"

JMIRx Med 2020;1(1):e24765

URL: https://med.jmirx.org/2020/1/e24765/

doi: $10.2196 / 24765$

PMID:

CEric Abbott. Originally published in JMIRx Med (https://med.jmirx.org), 19.10.2020. This is an open-access article distributed under the terms of the Creative Commons Attribution License (https://creativecommons.org/licenses/by/4.0/), which permits unrestricted use, distribution, and reproduction in any medium, provided the original work, first published in the JMIRx Med, is properly cited. The complete bibliographic information, a link to the original publication on https://med.jmirx.org/, as well as this copyright and license information must be included. 